\title{
The Degree of Dissemination of the Idea of Sustainable Development in Polish Housing Cooperatives in the Light of Empirical Research
}

\author{
Aneta Brzeska ${ }^{1, *(\mathbb{D})}$ and Sławomir Jędrzejewski ${ }^{2}$ \\ 1 Faculty of Economics, Finance and Management, University of Szczecin, 71-101 Szczecin, Poland \\ 2 Faculty of Management, University of Lodz, 90-237 Lodz, Poland; slawomir.jedrzejewski@uni.lodz.pl \\ * Correspondence: aneta.brzeska@usz.edu.pl
}

check for updates

Citation: Brzeska, A.; Jẹdrzejewski, S. The Degree of Dissemination of the Idea of Sustainable Development in Polish Housing Cooperatives in the Light of Empirical Research. Sustainability 2021, 13, 5481. https:// doi.org/10.3390/su13105481

Academic Editor: Grazia Napoli

Received: 22 March 2021

Accepted: 10 May 2021

Published: 13 May 2021

Publisher's Note: MDPI stays neutral with regard to jurisdictional claims in published maps and institutional affiliations.

Copyright: (C) 2021 by the authors. Licensee MDPI, Basel, Switzerland. This article is an open access article distributed under the terms and conditions of the Creative Commons Attribution (CC BY) license (https:// creativecommons.org/licenses/by/ $4.0 /)$.

\begin{abstract}
The cooperative movement was, in a way, the forerunner of the concept of corporate social responsibility (CSR), which is due to the fact that they operate on the basis of cooperative values such as democracy, equality, solidarity, membership and social responsibility, concern for the local community. An integral part of the implementation of corporate social responsibility is the publication of sustainability reports which are currently not published by Polish housing cooperatives. The aim of this article has been defined as the identification and assessment of the idea of sustainable development implemented on the basis of General Standard Disclosures and Specific Standard Disclosures indicators presented in the reporting of housing cooperatives compliant with the Global Reporting Initiative (GRI) G4 Guidelines on Sustainability Reporting. The research used the method of literature analysis and the method of observation, as well as a comparative analysis of the information disclosures presented by the housing cooperatives studied. The obtained research results confirmed the cognitive value of non-financial reports and disclosures of information on websites in the assessment of the implementation of the sustainable development strategy. The findings have signaled the need to disseminate the idea of CSR reports among housing cooperatives and to make their preparation mandatory.
\end{abstract}

Keywords: sustainable finance management; housing cooperative; sustainability reporting; theory of sustainable value

\section{Introduction}

The literature analysis carried out by the authors indicates a gap in the area of reporting on the sustainable development of housing cooperatives. By combining the stakeholder theory, the social contract theory, the agency theory, the legitimacy theory, the contingency theory and the institutional theory, the aim of the article has been defined as the identification and assessment of implemented strategies of sustainable development on the basis of General Standard Disclosures and Specific Standard Disclosures indicators presented in the reporting of housing cooperatives compliant with the Global Reporting Initiative (GRI) G4 Guidelines on Sustainability Reporting.

In pursuit of this formulated aim of the article, current regulations and the results of previously conducted research concerning the international and domestic market were reviewed. This review shows, among others, that the introduced mandatory non-financial reporting, along with a set of instruments encompassing various standards, has created the conditions for conducting research in the field of information content of reports. Among the regulations in the area covering the subject of this publication, one should cite Directive 2014/95/EU of the European Parliament and of the Council of 22 October 2014 on the disclosure of non-financial and diversity information by certain large undertakings and groups. Moreover, the growing interest in issues related to corporate social responsibility and its effects is confirmed by the extensive theoretical and empirical literature in this 
field [1]. W. Skoczylas has carried out a detailed review of standards and their classification, conducting theoretical and empirical research [2], which indicates a gap to which particular attention should be paid: the need for research on the structure of disclosed non-financial information which forms the basis for the assessment of corporate social responsibility of organizations by interested parties.

Corporate social responsibility and sustainability reporting have already been extensively described in the literature devoted to the theoretical aspects of this issue and empirical findings. However, the considerations of researchers in this area do not apply to housing cooperatives but to other entities characterized by the nature of operations that are different from those of housing cooperatives. It should be noted that research on housing cooperatives in Poland and in the world is very rarely conducted, and researchers focus mostly on entities with other organizational and legal forms whose operation is profitoriented. Despite the scarcity of such studies, a few examples were found. These studies are important because of their reference to cooperatives, though they are not related to housing cooperatives, which are the subject of the research presented in this article. Those are therefore studies conducted on entities that are only similar in their characteristics to housing cooperatives.

The research conducted by A. Lemańska-Majdzik shows that one for-profit housing cooperative expressed "the need to adopt a culture of sustainable development in its activities" [3] in the context of the social dimension of stakeholders' expectations. Environmentfriendly activities were undertaken when they were translated into the economic aspect [3].

B. Mazur and K. Zimoch have identified the values communicated by Polish cooperatives on their websites and have made a critical analysis of whether the values are consistent with the values of sustainable development [4]. However, as in the previous case, the study concerned cooperatives whose activities are conducted on the assumption of making a profit.

A study has also been conducted on the corporate social responsibility of cooperatives in the Republic of Moldova. It indicates that Moldovan cooperative enterprises promote social awareness of CSR practices. The authors point out that the public should be informed about the social impact of cooperatives and be provided with an opportunity to comment on their activities, thus helping cooperatives to improve their CSR practices. The Internet and websites are mentioned as the research tool. Eleven benefits of corporate social responsibility of cooperatives, which may contribute to their competitive advantage, were also listed [5].

The study presented in this article contributes to the existing literature. It is one of the first studies to provide evidence in the context of disclosure of information on sustainable development in Polish housing cooperatives. The authors' intention is for this publication to introduce to the literature a discussion on sustainable development in the context of its social aspect and role played in the development of housing cooperatives, with particular emphasis on regulatory aspects and social needs. The article fills the gap in the discussion on CSR and the research gap in the field of theoretical knowledge supported by empirical research in relation to non-financial reporting of Polish housing cooperatives taking into account the concept of CSR. Due to the aim of the article, the following types of verification were conducted:

1. Logical verification using the method of conducting in-depth studies of domestic and foreign literature related to the subject of the article;

2. Empirical verification using the method of observation.

The results will be useful for the management of housing cooperatives implementing, or planning to implement, CSR reporting. This is due to the fact that, as noted by W. Skoczylas, the implementation of corporate social responsibility management is stimulated by potential benefits such as building a reputation, improving relations with important stakeholders, expanding the ability to acquire and retain clients (i.e., members in the case of housing cooperatives) and employees, value creation of the entity, as well as the development of organizational culture and information culture [2]. 


\section{Polish Housing Cooperatives and Their Environment in the Context of CSR}

The national housing cooperative movement has its own history and long tradition, as well as economic and social achievements. However, both in Poland and across the world, legal, economic and social conditions are constantly changing, which requires constant adaptation to these changes from housing cooperatives (as from other entities). The degree of this adaptation depends to a large extent on the needs of people creating, interested in, and regulating the activities of housing cooperatives and the conditions in which they operate.

Housing cooperatives, as independent economic units, are co-creators of a market economy system [6]. They are distinguished by their nature from other economic units as they constitute a combination of an association and an enterprise [7] (p. 7). This association, in the interest of its members, carries out joint economic activities [8]. Overall, in Poland, there are 14,615,100 dwellings with a total area of 1,084,166.50 $\mathrm{m}^{2}$. The share of Polish housing cooperatives in the Polish housing stock is $14 \%$, representing 2,029,900 dwellings with a total area of $100,085.30 \mathrm{~m}^{2}$ [9].

Housing cooperatives manage dwellings which are sometimes the fruit of lifetime of work of housing cooperative members. The Auditing Union of Housing Cooperatives of the Republic of Poland has stated that "currently the housing cooperative movement is the best organized, has the strongest economic potential, as well as the largest number of members. There are 3600 cooperatives in Poland with 4,200,000 members. It is a huge community associated on the basis of voluntary decisions, equality and self-governance" [10]. It can be concluded that the overt goal of the housing cooperative is to improve the living conditions of its members by increasing their safety and satisfaction, and the covert goal is to increase the profitability of assets through lower operating and management costs [11].

Due to the indicated number of members of housing cooperatives, their information needs ought to be identified. Other entities interested in the operation of housing cooperatives and their effectiveness should also be determined (Table 1).

Source: own elaboration based on References [12,13].

In view of the progressive development of management practice and theory, the forms of satisfying users' information needs are also evolving. After identifying and grouping the needs, it can be seen that, in practice, a particular type of information corresponds to a specific group of recipients with specific information needs (Table 1). The recognition of their needs based on dialogue as well as respect and care for the common comfort of life is a test of corporate social responsibility of the housing cooperative and, at the same time, a pillar of its sustainable development. At this point, one can quote the definition proposed by J. Michalak stating that: "sustainable development means meeting the needs of the present generation without depriving future generations of their ability to satisfy their own needs. Sustainability reporting is about measuring as well as disclosing information and being accountable to internal and external stakeholders for sustainable performance. Sustainability reports are designed to compare an organization's social and environmental performance over time and to other organizations" [14].

Taking into account the above-mentioned definition in the context of housing, its sustainable development should meet the housing needs of the current generation without depriving future generations of the possibility of living in the housing cooperative stock. The goals of GRI sustainability reports take into account the stakeholders: "the reporting organization shall identify its stakeholders and explain how it has responded to their reasonable expectations and interests. This presents challenges in balancing the specific interests/expectations of stakeholders who can reasonably be expected to use the report with broader expectations of accountability to all stakeholders" [15].

The voluntary preparation and presentation of sustainability reports by housing cooperatives can be explained on the basis of a number of theories, for example, the stakeholder theory, the social contract theory, the agency theory, the legitimacy theory, the contingency theory, or the institutional theory. 
Table 1. Housing cooperative stakeholders and their information needs.

\begin{tabular}{|c|c|}
\hline Stakeholders & Information Needs \\
\hline Members & $\begin{array}{c}\text { They are interested, among others, in proper fulfilment by the housing } \\
\text { cooperative of its goal (satisfying their housing needs) and in information } \\
\text { on the adequacy, effectiveness and efficiency of management of the } \\
\text { housing cooperative and its resources. }\end{array}$ \\
\hline $\begin{array}{l}\text { The management } \\
\text { (Management Board/ } \\
\text { Supervisory Board) }\end{array}$ & $\begin{array}{l}\text { The management need additional management and financial information, } \\
\text { though they have access to it, to help them fulfil their planning, } \\
\text { decision-making, oversight, and control responsibilities. In the event of a } \\
\text { change of the Management Board, they need information whether the } \\
\text { previous management carried out its activities in accordance with } \\
\text { applicable regulations and proper management principles (legitimacy of } \\
\text { incurred expenses, compliance with tender procedures, compliance of } \\
\text { adopted resolutions with applicable law). }\end{array}$ \\
\hline Investors & $\begin{array}{l}\text { Members who own housing units in the housing stock managed by the } \\
\text { housing cooperative as well as other venture capital investors and their } \\
\text { advisers are interested in the magnitude of the inherent risk of } \\
\text { investments made by the housing cooperative and their rate of return. } \\
\text { They need information to help determine whether to acquire, hold or sell } \\
\text { a given investment. } \\
\text { They are interested in information enabling them to evaluate the activities } \\
\text { of the housing cooperative. }\end{array}$ \\
\hline Employees & $\begin{array}{l}\text { They are interested in information on the stability and profitability of the } \\
\text { housing cooperative, information that enables them to assess the ability of } \\
\text { the housing cooperative to pay wages and retirement benefits, as well as } \\
\text { to create jobs. }\end{array}$ \\
\hline Lenders & $\begin{array}{l}\text { They are interested in information that allows them to determine whether } \\
\text { their loans along with interest on these loans will be repaid on the } \\
\text { agreed date. }\end{array}$ \\
\hline Suppliers and creditors & $\begin{array}{l}\text { They are interested in information enabling them to determine whether } \\
\text { they will receive the amounts due on time. }\end{array}$ \\
\hline $\begin{array}{l}\text { Future members-potential } \\
\text { customers }\end{array}$ & $\begin{array}{l}\text { They are interested in information on the continued operation of the } \\
\text { housing cooperative as they want to maintain their relationship with the } \\
\text { housing cooperative long-term and will be dependent on it. }\end{array}$ \\
\hline $\begin{array}{l}\text { Government and government } \\
\text { agencies, including the } \\
\text { Auditing Union of Housing } \\
\text { Cooperatives of the Republic of } \\
\text { Poland and the National } \\
\text { Cooperative Council }\end{array}$ & $\begin{array}{c}\text { They are interested in allocating resources, hence their interest in the } \\
\text { activities of housing cooperatives. They also need information to regulate } \\
\text { these activities, define the tax policy, calculate national income and other } \\
\text { statistical data. Cooperative associations-the Auditing Union of Housing } \\
\text { Cooperatives of the Republic of Poland. Tax authorities-tax } \\
\text { enforcement/collection. }\end{array}$ \\
\hline $\begin{array}{l}\text { Society: } \\
\text { - } \quad \text { entire society } \\
\text { local community }\end{array}$ & $\begin{array}{l}\text { Housing cooperatives influence society in various ways: they contribute } \\
\text { to the cultural activities of the families of cooperative members and } \\
\text { contribute to the local economy by employing workers. Society members } \\
\text { need information on trends and recent changes in the level of wealth and } \\
\text { profitability of the housing cooperative and its scope of activities. }\end{array}$ \\
\hline
\end{tabular}

Referring to the stakeholder theory, it should be noted that the stakeholders depend on the housing cooperative and are influenced by its actions directly or indirectly, for example, as a result of agreements or contracts concluded. Each of the stakeholders is therefore interested in the housing cooperative's overall activities and their effects. In sustainability reports, housing cooperatives (similarly to businesses) should present environmental, social and economic sustainability impacts, thus taking into account various interest groups. It would allow housing cooperatives to avoid possible social opposition towards any actions taken (e.g., avoiding protests of environmental organizations when constructing new residential buildings, playgrounds, or sports facilities).

According to the social contract theory, society is perceived through the network of contacts among its various members. CSR activities are then analyzed in two dimensions: macro-contracts and micro-contracts. Macro-contracts define the relationships and expectations between society or local community and economic activity. Micro-contracts concern relationships between individuals [16]. 
The analysis of the behavior of members and management of a given entity shows that decisions made may be determined by the need to verify the activities of the housing cooperative, which is related to the issues of the agency theory [17] (According to the definition of M. C. Jensen and W. H. Meckling, it is "a contract under which one or more persons (the principal (s)) engage another person (the agent) to perform some service on their behalf which involves delegating some decision making authority to the agent" — see more [17]). It is therefore important to clarify the relationship between the principal (a member of the housing cooperative) and the agent (managing the housing cooperative) hired to manage the property of the principal. The agency theory indicates a situation in which the principal is not able to verify the correctness of the agent's actions, as this monitoring is costly and difficult to perform [18]. S. B. Graves and S. A. Waddock have found that agents (managers) are more inclined to take actions for sustainable development, as they participate to a lesser extent in the distribution of the company's profits in the long term. The authors emphasize that these actions may positively influence the evaluation of agents' work as this way managers will not be accused of acting to the detriment of society [19]. Similarly, a president who takes into account the sustainable development of the housing cooperative in management decisions is also more likely to maintain his/her position. The housing cooperative president can use sustainability reporting to improve his/her reputation and increase public recognition. Housing cooperative members can also benefit greatly from these reports. However, due to the costs of preparing a sustainability report, which increase the entity's operating costs, this group of stakeholders may be less inclined to develop this form of reporting, even if it translates into a better perception of the entity by its environment.

The considerations contained in this publication are also embedded in the contingency theory (already present in organizational studies in the 1960s [20]) due to the fact that information cycles are analyzed as an effect of specific external and internal determinants of the housing cooperative's operation. For this reason, in the further part of the article, an attribute of this theory will be used allowing for the application of a universal description and the explanation of phenomena specific to housing cooperatives [21] (p. 324). Due to the fact that the subordination of housing cooperative activities to legitimacy, social norms and legal regulations and the adaptation of results of its activities, in the form of sustainability reports, to the information needs of internal and external stakeholders are associated with the legitimacy theory, this theory is used to explain why housing cooperatives (or companies) decide to voluntarily submit sustainability information.

The research conducted for the purposes of this publication is also based on the institutional theory (used interchangeably with the stakeholder theory and the legitimacy theory) serving to explain motivations for sustainable development, combining the practice of housing cooperatives with the norms of society in which they operate. Voluntary disclosure by housing cooperatives of information on sustainability is perceived as part of an institutional practice aimed at maintaining, acquiring, or regaining their legitimacy. Housing cooperatives adopt institutional practices through isomorphic processes such as coercion, imitation, and normative pressures. The need to address concerns about threats to organizational legitimacy plays to a large extent the role of a potential driving force for disclosure of information on sustainable development [22]. This means that housing cooperatives are appropriate entities to implement the principles of sustainable development with the involvement of residents [23]. It should be emphasized that housing cooperatives, due to the specificity of their activities, take into account the requirements of sustainable development and act to promote it. The concept of cooperatives is therefore inherently related to the goals and tasks of sustainable development. These goals (Sustainable Development Goals-SDG) emphasize the corporate social responsibility of housing cooperatives. The 11th goal of the resolution adopted by the United Nations General Assembly on 25 September 2015 "Transforming Our World: the Agenda 2030 for Sustainable Development" sets out to "make cities and human settlements inclusive, safe, resilient and sustainable" comprising tasks related to the operation of housing cooperative: 
- “11.1 By 2030, ensure access to adequate, safe and affordable housing and basic services and upgrade slums;

- $\quad$ 11.3 By 2030, enhance inclusive and sustainable urbanization and capacity for participatory, integrated and sustainable human settlement planning and management in all countries;

- $\quad$ 11.4 Strengthen efforts to protect and safeguard the world's cultural and natural heritage" [24].

It is a worldwide outlook of the problem which shows how important the issue of housing is in the 2030 time horizon from the national, EU and global perspective.

The use of CSR as a method of managing a housing cooperative means that the housing cooperative becomes an active organization, responding to changes in its socio-economic and cultural environment. The housing cooperative builds a stable position on the basis of long-term activities focused on broadly understood development through establishing a network of social relations with its environment. These are premises for perceiving this form of organization as active and acquiring knowledge through experience.

There is an increase in social awareness of housing cooperative members, who are becoming more demanding, and are driven by trust in the housing cooperative and its image. Therefore, the sustainable development of housing cooperatives can increase the loyalty of their members and suppliers/stakeholders. Pro-environmental and pro-social activities of these cooperative organizations may contribute to gaining the favor and a greater level of trust of local government authorities and the local community. The indicated activity is part of the non-financial motivation of housing cooperative employees, who may start to improve the perception of their employer based on the code of ethics implemented or involvement in matters important to people. This way, housing cooperatives can improve their labor market image.

One can agree with the position of R. Konieczna that sustainable development is an obligation [25] (p. 29) which the housing cooperative voluntarily accepts and then includes in its management system, as CSR is increasingly desired and required by stakeholders (primarily its members).

\section{Materials and Methods}

The empirical study of the prevalence of sustainability reports was conducted in the period from December 2019 to December 2020 using the observation method. Observation as a research method should be carried out intentionally and in a planned manner so that it does not affect the process, phenomenon, or object under observation. This method assumes the selection of observations according to predetermined conditions, which are subject to appropriate selection. The selection criterion is determined based on the purpose of the study. The observation method as a research method takes into account all stages of research activities, which means that it allows us, among others, to set objectives, collect specific data, verify and select research material. It also provides the conditions for conducting the preliminary study and the main study. This method also specifies how research techniques or tools may be prepared and used. The observations that are the basis for the analysis of the results of the research are recorded in protocols (or questionnaires), which makes it possible to make scientific generalizations [26] (pp. 62-63). The study presented was carried out in accordance with the research methodology shown in Figure 1. 


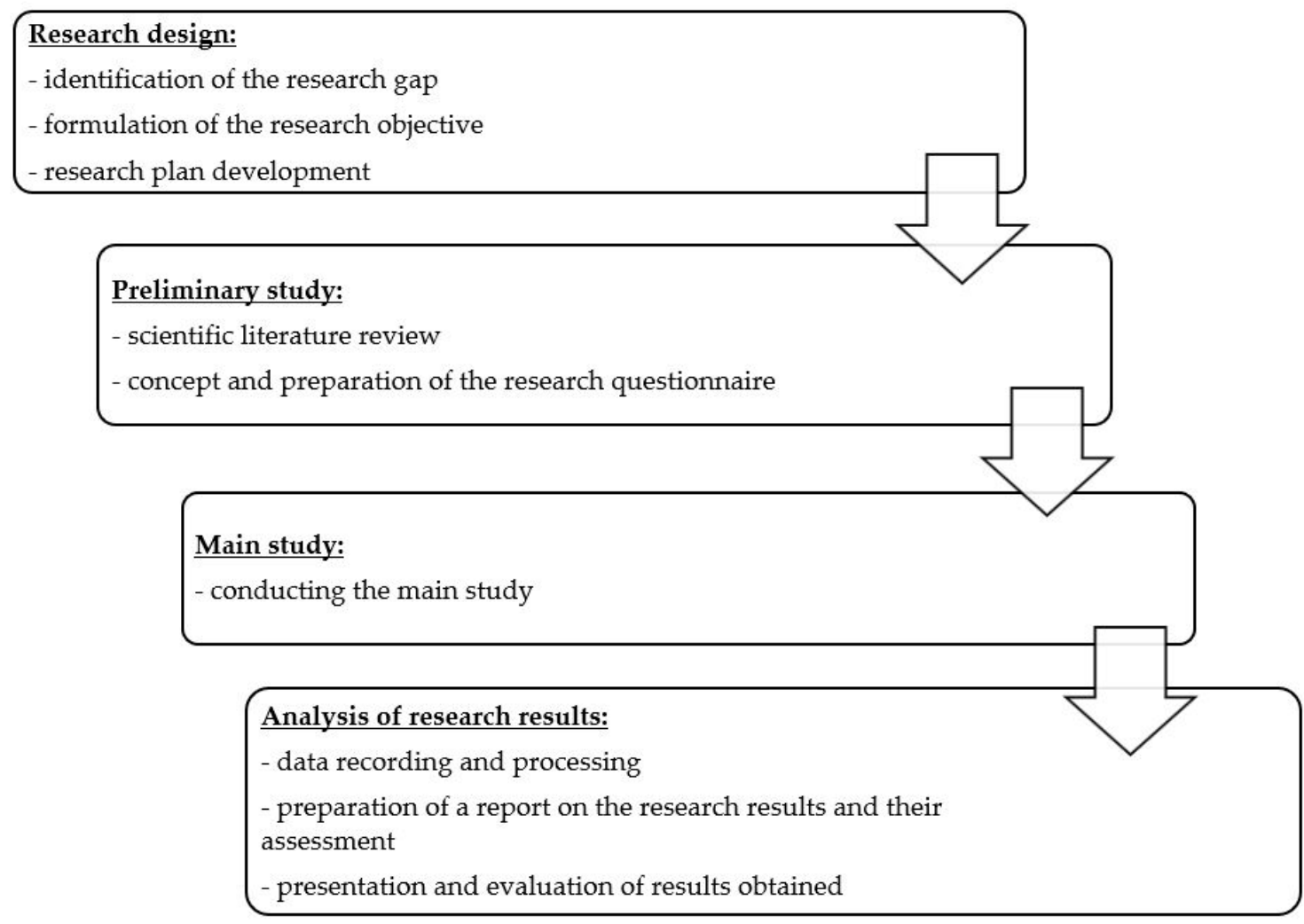

Figure 1. Research methodology.

The first stage in the implementation of the undertaken research task was the identification of the research gap as well as the formulation of the objective of the study and the preparation of the research plan. The analysis of the theoretical assumptions of the CSR concept and the instruments for its implementation postulated in the literature, set the research directions for the conducted study. In pursuit of thus formulated purpose of the study, the research questionnaire was prepared, in terms of content, in line with the standards of sustainability reporting, specifically with the Global Reporting Initiative G4 Guidelines on Sustainability Reporting (Table A1). The research questionnaire is presented in more detail in Appendix A. This means that the issues of sustainable reporting discussed in the article and the conducted study refer to standards developed by the Global Reporting Initiative, which are the most advanced and most widely used standards in business practice. The GRI G4 standards contain internationally agreed indicators and measures presenting the most important issues related to the sustainable development of a given organization. Therefore, the indicators and information disclosures provided by the reporting entities divided into the following groups formed the basis for the assessment:

1. General Standard Disclosures in the basic version, that is, indicators reflecting the scope of the strategy and analysis implemented, the profile of the housing cooperative, the material aspects identified and their boundaries, stakeholder engagement, report profile, organizational governance, and ethics;

2. Specific Standard Disclosures, including information on the approach to management, as well as indicators in economic, environmental and social categories (further broken down into subcategories: employment and decent work practices, human and community rights, and product responsibility which, in the case of a housing cooperative will be responsibility, for example, for a dwelling) [27] (pp. 18-235).

The assessment was made on the basis of a comparative analysis of the structure indicators reported by the Polish housing cooperatives surveyed and the structure indicators of the GRI 4 standards, including the intensity indicator (which is the ratio of the indicators 
reported by housing cooperatives to the possible scope of reporting defined by the GRI standards [2]).

The empirical study of the prevalence of sustainability reports included 100 housing cooperatives operating in Poland. The collection of non-financial data was done manually and several sources were used to compile the dataset. In the first stage, the search mechanism on the website of the National Court Register was employed to find 100 housing cooperatives. For this purpose, the "cooperative" keyword was entered in the search field of the website. The website search mechanism found many cooperatives, and on the basis of the list received, the first 100 housing cooperatives were selected for the research sample. Then, non-financial reports for the selected housing cooperatives for 2018 were collected. In addition, the existence of disclosures in sustainability development reports, coded in line with the GRI G4 indicators, was checked and identified to measure the amount and variety of certain types of information. Relevant indicators recognized by the reporting entities, resulting from their strategy, were divided into two groups: the General Standard Disclosures and the Specific Standard Disclosures, formed the basis for the assessment of each housing cooperative conducted in the study.

Subsequently, the content of websites and other communication tools of the housing cooperatives studied was analyzed in order to search for declarations whether the ideas of sustainable development were important for the management.

For the above-presented research stages, a binary measure was used to record voluntary disclosure of information on sustainable development in the research questionnaire. If a given housing cooperative provided information on the issues analyzed in the form of non-financial reports or website disclosures, that fact was coded as " 1 ".

In the final stage, the structure of information disclosures and sustainability declarations was observed and analyzed. The results were compiled using the percentage share and the intensity index was calculated.

Data sources were limited to non-financial reports, websites and annual reports of the housing cooperatives studied.

\section{Results}

As a result of the above-presented research, it was possible to analyze the information available on the relevant websites and in annual reports posted on the website of the National Court Register ICT system. According to the GRI G4 standards, first, one learns about a given organization, including: the importance of sustainable development for the organization and the actions taken to implement it, the characteristics and scale of the organization, organizational governance, and ethics. The General Standard Disclosures indicators, comprising the first group of indicators, make it possible to refer to the report as a source of information in which a given organization describes the process leading to the achievement of the goal of defining the content of the report, identifying material aspects and their boundaries, compiling data, indicating stakeholder engagement (not only for the purpose of reporting) and report profile [2].

The structure of the GRI G4 standards allows one to first familiarize oneself with the first group of indicators describing a given housing cooperative- the General Standard Disclosures indicators. The Specific Standard Disclosures indicators, on the other hand, are an important source of information when assessing the implementation of the sustainable development strategy, as they reflect the impact of housing cooperatives on the environment and society, significantly influencing the assessment and decision of both internal and external stakeholders.

Analyzing the two groups of indicators makes it possible to familiarize oneself with their structure. As indicated by the research results presented in Table 2, the assessed content of reports of the housing cooperatives studied differs significantly from that resulting from the GRI G4 standards (i.e., the reported content constitutes only $37 \%$ of the scope covered by the GRI G4 standards). 
Table 2. General Standard Disclosures and Specific Standard Disclosures.

\begin{tabular}{cccccc}
\hline Indicators & $\begin{array}{c}\text { Sum of Reported } \\
\text { Indicators }\end{array}$ & Share \% & $\begin{array}{c}\text { Sum of GRI G4 } \\
\text { Indicators }\end{array}$ & Share \% & $\begin{array}{c}\text { Intensity } \\
\text { Index } \mathbf{1}^{-}\end{array}$ \\
\hline $\begin{array}{c}\text { General } \\
\text { Standard } \\
\text { Disclosures }\end{array}$ & 1792 & 60.8 & 34 & 42.5 & 52.7 \\
\hline $\begin{array}{c}\text { Specific } \\
\text { Standard } \\
\text { Disclosures }\end{array}$ & 1156 & 39.2 & 46 & 57.5 & 25.1 \\
\hline Total & 2948 & 100 & 80 & 100 & 36.9 \\
\hline
\end{tabular}

${ }^{1}$ The ratio of reported content in relation to the standard scope after [2].

Based on the General Standard Disclosures listed in Table 3, it can be seen that housing cooperatives do not declare the implementation of sustainable development strategy, but they present their report profile or organizational profile and organizational governance.

Table 3. List of General Standard Disclosures.

\begin{tabular}{|c|c|c|c|c|c|}
\hline Indicators & $\begin{array}{l}\text { Sum of Reported } \\
\text { Indicators }\end{array}$ & Share \% & $\begin{array}{l}\text { Sum of GRI G4 } \\
\text { Indicators }\end{array}$ & Share $\%$ & $\begin{array}{l}\text { Intensity } \\
\text { Index }\end{array}$ \\
\hline $\begin{array}{l}\text { Strategy and } \\
\text { Analysis }\end{array}$ & 0 & 0 & 1 & 2.9 & 0 \\
\hline $\begin{array}{l}\text { Organisational } \\
\text { Profile }\end{array}$ & 862 & 48.1 & 14 & 41.2 & 61.6 \\
\hline $\begin{array}{l}\text { Identified } \\
\text { Material } \\
\text { Aspects and } \\
\text { the Corre- } \\
\text { sponding } \\
\text { Boundaries }\end{array}$ & 200 & 11.2 & 7 & 20.6 & 28.6 \\
\hline $\begin{array}{l}\text { Stakeholder } \\
\text { Engagement }\end{array}$ & 121 & 6.8 & 4 & 11.8 & 30.3 \\
\hline $\begin{array}{l}\text { Report } \\
\text { Profile }\end{array}$ & 480 & 26.8 & 6 & 17.6 & 80.0 \\
\hline $\begin{array}{l}\text { Organisational } \\
\text { Governance }\end{array}$ & 81 & 4.5 & 1 & 2.9 & 81.0 \\
\hline Ethics & 48 & 2.7 & 1 & 2.9 & 48.0 \\
\hline Total & 1792 & 100 & 34 & 100 & 52.7 \\
\hline
\end{tabular}

In the dialogue with the internal and external environment, the name of the organization, its basic services, headquarters, location, and legal form, as well as the scale of the organization, the number of employees broken down by type of employment and gender, its reporting periods, the structure of its management bodies, along with changes in those areas were widely reported. The key issues and matters raised by stakeholders in the reporting period were presented to a slightly lesser extent (67\%). In 53\% of the housing cooperatives considered, the undertaken economic, environmental or social initiatives and norms of behavior were listed in the form of rules of conduct.

The list of selected Specific Standard Disclosures presented in Table 4, specific to the sector of housing cooperatives (but not obligatory), made it possible to present the structure of information published by the housing cooperatives analyzed against the GRI G4 benchmark in the context of material aspects, reflecting the significant impact of cooperatives on the economy, natural environment and society, or significantly influencing stakeholder assessments and decisions. 
Table 4. List of selected Specific Standard Disclosures.

\begin{tabular}{cccccc}
\hline $\begin{array}{c}\text { Indicators } \\
\text { by Aspects }\end{array}$ & $\begin{array}{c}\text { Sum of Reported } \\
\text { Indicators }\end{array}$ & Share \% & $\begin{array}{c}\text { Sum of GRI G4 } \\
\text { Indicators }\end{array}$ & Share \% & $\begin{array}{c}\text { Intensity } \\
\text { Index }\end{array}$ \\
\hline $\begin{array}{c}\text { Economic } \\
\text { category }\end{array}$ & 205 & 17.7 & 4 & 8.7 & 51.3 \\
\hline $\begin{array}{c}\text { Environmental } \\
\text { category }\end{array}$ & 416 & 36.0 & 12 & 26.1 & 34.7 \\
\hline $\begin{array}{c}\text { Social } \\
\text { category }\end{array}$ & 535 & 46.3 & 30 & 65.2 & 17.8 \\
\hline Total & 1156 & 100 & 46 & 100 & 25.1 \\
\hline
\end{tabular}

The results indicate that the scope of information enabling the assessment of actions taken to implement the declared strategy compared to the scope agreed in the standards covers approximately $25.1 \%$ of possible aspects, that is, $51.3 \%$ of the aspects of the indicators from the economic category, $34.7 \%$ of the aspects of the indicators from the environmental category, and $17.8 \%$ of the aspects of the indicators from the social category.

The share of the amount of information classified according to the GRI G4 Specific Standard Disclosures in the economic category is presented in Table 5. The list shows that almost half of the housing cooperatives studied presented economic performance $(47.8 \%)$ in the economic category, while a minority indicated indirect economic impacts $(12.7 \%)$ or market presence $(18.5 \%)$.

Table 5. List of selected indicators according to the aspects of the economic category.

\begin{tabular}{ccc}
\hline Indicators & Sum of Reported Indicators & Share \% \\
\hline Economic Performance & 98 & 47.8 \\
\hline Market Presence & 38 & 18.5 \\
\hline Indirect Economic Impacts & 26 & 12.7 \\
\hline Procurement Practices & 43 & 21.0 \\
\hline Total & 205 & 100 \\
\hline
\end{tabular}

The activities of housing cooperatives should also be aimed at environmental protection. Most often they relate to energy and water consumption as well as the costs of sewage disposal and waste management (see Table 6), that is, a list of selected indicators from the environmental category relevant to the activities of housing cooperatives. Housing cooperatives most often show the costs incurred in the indicated aspects broken down by real estate properties, by comparing their amount to the previous year, additionally pointing to possible reasons for their changes.

Only in a few cases do housing cooperatives share information on the effectiveness of actions taken, for example, in terms of reducing greenhouse gas emissions. However, no environmental assessment of the impact of deliveries or employee transport on the environment was reported. Therefore, it can be assumed that such activities are not included in their sustainable development strategy.

By listing the indicators according to the aspects of the social category, the structure of indicators the most widely presented by the housing cooperatives studied was obtained, as shown in Table 7. 
Table 6. List of selected indicators according to the aspects of the environmental category.

\begin{tabular}{ccc}
\hline Indicators & Sum of Reported Indicators & Share $\%$ \\
\hline Materials & 68 & 16.3 \\
\hline Energy & 73 & 17.5 \\
\hline Water & 72 & 17.3 \\
\hline Biodiversity & 1 & 0.2 \\
\hline Emissions & 12 & 2.9 \\
\hline Effluents and waste & 72 & 17.3 \\
\hline Products \& Services & 65 & 15.6 \\
\hline Compliance & 40 & 9.6 \\
\hline Transport & 0 & 0.0 \\
\hline Overall & 12 & 2.9 \\
\hline Supplier Environmental Assessment & 0 & 0.0 \\
\hline Environmental Grievance Mechanisms & 1 & 0.2 \\
\hline Total & 416 & 100 \\
\hline
\end{tabular}

Table 7. List of selected indicators according to the aspects of the social category.

\begin{tabular}{|c|c|c|}
\hline Indicators & Sum of Reported Indicators & Share \% \\
\hline 1. Labor Practices and Decent Work & 127 & 23.7 \\
\hline Employment & 89 & 16.6 \\
\hline Employee/Management Relations & 13 & 2.4 \\
\hline Occupational Health and Safety & 11 & 2.1 \\
\hline Training and Education & 10 & 1.9 \\
\hline Diversity and Equal Opportunity & 1 & 0.2 \\
\hline Equal Remuneration for Women and Men & 1 & 0.2 \\
\hline Supplier Assessment for Labor Practices & 0 & 0.0 \\
\hline Labor Practices Grievance Mechanisms & 2 & 0.4 \\
\hline 2. Human Rights & 12 & 2.2 \\
\hline Investment & 0 & 0.0 \\
\hline Non-discrimination & 1 & 0.2 \\
\hline $\begin{array}{l}\text { Freedom of Association and } \\
\text { Collective Bargaining }\end{array}$ & 0 & 0.0 \\
\hline Child Labor & 4 & 0.7 \\
\hline Forced and CompulsoryLabor: & 1 & 0.2 \\
\hline Security Practices & 5 & 0.9 \\
\hline Indigenous Rights & 0 & 0.0 \\
\hline Periodic Assessment System & 1 & 0.2 \\
\hline Supplier Human Rights Assessment & 0 & 0.0 \\
\hline Human Rights Grievance Mechanisms & 0 & 0.0 \\
\hline
\end{tabular}


Table 7. Cont.

\begin{tabular}{|c|c|c|}
\hline Indicators & Sum of Reported Indicators & Share \% \\
\hline 3. Society & 156 & 29.2 \\
\hline Local Communities & 59 & 11.0 \\
\hline Anti-corruption & 1 & 0.2 \\
\hline Public Policy & 38 & 7.1 \\
\hline Anti-competitive Behavior & 4 & 0.7 \\
\hline Compliance & 41 & 7.7 \\
\hline Supplier Assessment for Impacts on Society & 0 & 0.0 \\
\hline Grievance Mechanisms for Impacts on Society & 13 & 2.4 \\
\hline $\begin{array}{l}\text { 4. Product Responsibility Performance } \\
\text { Indicators (e.g., responsibility for buildings) }\end{array}$ & 240 & 44.9 \\
\hline $\begin{array}{l}\text { Customer Health and Safety (here: customers are } \\
\text { housing cooperative members) }\end{array}$ & 74 & 13.8 \\
\hline Product and Service Labelling & 11 & 2.1 \\
\hline Marketing Communications & 25 & 4.7 \\
\hline $\begin{array}{l}\text { Customer Privacy (here: privacy of housing } \\
\text { cooperative members) }\end{array}$ & 56 & 10.5 \\
\hline Compliance & 74 & 13.8 \\
\hline Total & 535 & 100.0 \\
\hline
\end{tabular}

The presented structure (Table 7) indicates that the greatest importance $(44.9 \%)$ in the implementation of the sustainable development strategy is attributed to activities included in the sub-category of product responsibility (which in the case of housing cooperatives is real estate). Particular attention is paid to the health and safety of housing cooperative members, compliance with regulations, and ensuring the privacy of housing cooperative members. The second most important are activities related to society $(29.2 \%)$, especially in the field of local communities, rules concerning participation in public life, or compliance with regulations. Less importance is attached to labor practices and decent work, where employment is primarily reported. The subcategory related to respecting human rights, where mainly practices related to employee occupational health and safety were reported, is the most ignored area.

The conducted research indicates that, among the additional activities within the framework of the sustainable development concept and corporate social responsibility mentioned by the housing cooperatives considered, both in their non-financial reports and on their websites, the following should be particularly noted:

1. An extensive program of "sustainable development and domestic hot water" implemented by one of the housing cooperatives;

2. Installation of water meters in residential premises allowing for remote reading;

3. A frequent phenomenon of awards given to housing cooperatives in categories such as: "significant environmental impact" for thermal modernization of buildings and reduction of $\mathrm{CO}_{2}$ emissions, or "clones" for entities that function in harmony with the natural environment;

4. Purchasing and selling by some housing cooperatives so-called "white certificates", important for environmental protection;

5. Implementing measures called "Housing Cooperative Greenery";

6. Declarations that funds are provided in the cost calculations of every project for land development after the completion of construction in such a way that any interference in the environment is compensated by the creation of a properly integrated building enriching the landscape; 
7. Concluding agreements with the Voivodeship Fund for Environmental Protection and Water Management concerning, for example, co-financing of comprehensive thermal modernization of multi-family buildings in the stock of housing cooperatives with the use of renewable energy installations and the Smart Energy Management System. The implementation of this kind of projects will result in the reduction of emissions of the economy by significantly improving energy efficiency of buildings, which will lead to the reduction of their energy consumption, lower operating costs, enhanced visual aesthetics, as well as an increase in the environmental awareness of housing estate residents;

8. Organizing Community Groups of local residents aimed at integrating the community of inhabitants of a given building and helping other bodies of the cooperative to identify and solve problems and needs of this community;

9. Organizing educational, artistic and entertainment activities for children, adolescents and adults;

10. Housing cooperative buildings often "drowning" in greenery. Creating a tab labelled "greenery and recreation" on housing cooperative websites;

11. Setting the sub-goal of adaptation to climate change, risk prevention and risk management by one of the housing cooperatives studied;

12. Publishing by another housing cooperative studied the information described under the "environmental protection" sub-category indicating that it is environmentfriendly; carrying out renovation works, it operates in accordance with the requirements of environmental protection, that is, provides "green zones" and good conditions for birds using the area;

13. Indicating that the housing cooperatives considered strive to reduce energy consumption by improving the thermal insulation parameters of external covers of their buildings (e.g.,: in one of the housing cooperatives analyzed, as a consequence of the implementation of such a project, there will be a reduction of $\mathrm{CO}_{2}$ emissions of seven tons per each building, and after investments in three buildings, a reduction of 21 tons, which shows the scale of possibilities in this regard);

14. Winning the first two awards for an ingenious and attractive design of the housing estate greenery which enriches the surroundings with different colors from spring to autumn by one of the housing cooperatives analyzed;

15. Including a point on "environmental protection" in the report on its activities by one of the housing cooperatives analyzed, pointing to modernization projects implemented over the years and bringing tangible results in the form of low fees for using the environment and no penalties for exceeding the emissions of harmful substances;

16. Improving the environmental living conditions by removing asbestos from multifamily residential buildings and using insulation made of other asbestos-free materials harmless to the human environment in the process of thermal modernization of buildings.

In one of the housing cooperatives considered, among the reports posted on the website, there was a presentation on the idea of sustainable development encompassing the following three spheres:

1. Environment-the reduction of emissions harmful to the environment; improving the quality of the natural environment; primary energy savings through energy production in high-efficiency cogeneration;

2. Society-improving the safety of residents; enhancing the quality of life of residents, increasing the awareness of residents related to the sustainable development of the city;

3. Business-improving energy efficiency; lowering operating costs; better use of production assets and transmission networks; increasing the availability of district heat for residents of the entire city.

Concluding the results of the conducted study, it can be stated that the scope of the presented indicators allows stakeholders to familiarize themselves with the profile 
of housing cooperatives. However, the Specific Standard Disclosures, indicating a direct and indirect impact of the activity on society and the natural environment, were reported rather narrowly in relation to the scope defined by the GRI G4 Guidelines. Nevertheless, it should be taken into account that these are "largely lagged, not leading indicators. The cognitive value of the latter is expressed in the fact that they reflect the achievement of the goal, the actions taken to achieve them, or the level of meeting the expectations of stakeholders" [28]. In the reports and on the websites, information is presented without following any uniform standard or guidelines adjusting the specific nature of housing cooperatives to CSR reporting. None of the housing cooperatives from the selected sample prepared sustainability reports in accordance with the GRI G4 Guidelines. The lack of actions taken in the field of CSR reporting among housing cooperatives (which in fact undertake this type of activities-as indicated in this article) is puzzling. After all, housing cooperatives have to fulfil the principles of sustainable development, for example, by meeting the needs of future generations.

\section{Discussion}

It should be noted that the presented research results indicate the realized sustainable development of housing cooperatives both in the social and environmental dimension. Housing cooperatives publish on their websites various non-financial reports and information related to environmental and social issues.

As a result of the study, it can be said that the concept of sustainable development in Polish housing cooperatives is still at its initial stage, treated as a synonym for sponsorship or charity, or implemented only in the form of occasional pro-social or environmental activities aimed at creating a certain image. Most housing cooperatives do not use this concept as an overall management strategy, which makes it very difficult to assess their activities in this area.

The theoretical issues and empirical research discussed in the article allowed for the identification of areas of sustainable development of housing cooperatives and basic information about it, which is of key importance for the assessment of its level. Based on the analysis of selected Polish housing cooperatives, it has been possible to determine what information about this specific type of entity and its activities is necessary to verify the level of its sustainable development.

Housing cooperatives should initiate a dialogue with stakeholders by preparing non-financial reports in accordance with the GRI G4 requirements in order to assume responsibility for employees and contractors in the supply chain and to monitor the impact of cooperatives on the natural environment.

The research results obtained have confirmed the cognitive value of non-financial reports and disclosures of information on websites when assessing the implementation of the sustainable development strategy. At the same time, the findings have pointed to the existing gap, as the content of these reports needs improvement, including the wider publication of Specific Standard Disclosures.

One can agree with the statement of E.I Szczepankiewicz and P. Mućko that the differences in the scope and form of presentation of financial and non-financial information make it difficult for stakeholders to compare the situation and quality of management of the entities analyzed or assess their prospective performance [29].

The research results provide decision-makers with theoretical and practical implications to encourage housing cooperatives in Poland and around the world to take actions aimed at sustainable development and disclosure of corporate social responsibility information.

General conclusions regarding the analysis of Polish housing cooperatives can be formulated as follows:

1. Housing cooperatives analyze their impact on the environment;

2. They have not developed and are not yet implementing reporting according to the concept of sustainable development; 
3. Initiatives to promote awareness of CSR among these entities should be introduced so that the successful popularization of sustainable development in this sector could be achieved quickly and CSR reporting could be implemented.

One can see a number of benefits from the implementation of the CSR reporting strategy in this area by housing cooperatives (not only in Poland but also worldwide). The introduction of CSR principles into housing cooperatives may lead to increased interest on the part of future members/potential investors, as they might be more willing to grant a loan or invest as a new member in purchasing a dwelling in a socially responsible and credible housing cooperative.

There are other benefits that housing cooperatives can achieve after implementing CSR principles:

1. Formation of trust-based and long-term relationships with external stakeholders (the local community, cooperating entities, investors, non-governmental organizations);

2. Building a competitive advantage and focusing on sustainable development;

3. Increasing resistance to the occurrence and consequences of random events or crisis situations;

4. Building an organizational culture that is appropriately transparent, based on cooperation and high ethical standards;

5. Creating a positive image (by strengthening the recognition among internal and external stakeholders, including the local community, public opinion, and market analysts);

6. Increasing workplace safety;

7. Creating a positive image in the eyes of potential job applicants, increasing employee satisfaction (loyalty and motivation);

8. Increasing the awareness of the impact of housing cooperatives on the natural environment among housing cooperative employees;

9. Creating a positive image of the housing cooperative management in the eyes of current and potential investors by initiating and carrying out activities in the area of CSR;

10. Reducing the negative impact on the natural environment by implementing a management system contributing to compliance with legal regulations in the field of environmental protection; faster detection and removal of any irregularities contributing to negative impacts on the environment;

11. Reducing the operating costs of housing cooperatives through rational consumption of raw materials, optimization of material selection (e.g., the materials used to build residential buildings), increasing the efficiency of infrastructure resources, reducing the costs of effluent and waste removal as well as the costs of related infrastructure, reducing fees for using the environment and lowering insurance rates;

12. Improving the image of the housing cooperative in the community, which will increase the trust of current and future housing cooperative members.

Housing cooperatives have at their disposal a growing set of various tools that facilitate the process of implementing CSR principles. The completion of the process of implementing these principles successfully depends on many situational factors, that is, economic, institutional, cultural, and social. The management board and the entire housing cooperative must be involved. The contemporary socially responsible model of housing cooperative management is not only about meeting formal requirements and legal obligations but about incorporating the idea of CSR into the management process in conjunction with the financial and investment policy of the housing cooperative.

It should be stressed that there are limitations to this study, firstly because of the size of the sample which consists of 100 housing cooperatives. The research was also limited territorially to housing cooperatives located in Poland. It should be also borne in mind that, in comparison to financial statements, the non-financial reports audited, for example, activity reports, have a lower level of credibility resulting from subjectivity and difficulties in verifying certain information. The published subjective opinions or interpretations of the 
management constitute an important and valuable part of the report. It should be noted, however, that a certain degree of subjectivity of the housing cooperative management influences the content of the report which after all aims to objectively present the image of a given entity. This makes comparisons difficult, as the choice of aspects and indicators remains in the sphere of individual motivations and decisions of housing cooperatives.

The conclusions drawn from the conducted empirical research suggest the need for further studies in this area and their diffusion into economic practice. The equally low percentage of Polish housing cooperatives promoting the idea of sustainable development in their non-financial reports indicates the need to promote these principles in the housing cooperative community. After all, as a sustainable and participatory organizational form, housing cooperatives should present an alternative business model for social organizations [30].

The presented study will contribute to expanding knowledge on the relationship between sustainable development and its impact on the housing cooperative sector. There is, however, a need for further more extended research on the issue conducted on a larger research sample, involving a comparative analysis of subsequent financial years. Future in-depth studies carried out in other countries may provide results that can be compared with this study.

As emphasized by R. Konieczna, "a properly prepared social report should enable the interested party to form an opinion on the overall picture of the activities" [25] (p. 41) of housing cooperatives and their effects. The authors have put forward the idea that housing cooperatives should prepare mandatory non-financial information (CSR) statements and reports that could be called corporate social responsibility reports of housing cooperatives.

Should CSR reporting therefore be mandatory for housing cooperatives in the future? Do housing cooperatives only undertake some activities in order to make their image more environment friendly? Will sustainability reports serve as public relations materials used to create the image of a given housing cooperative in the eyes of social groups instead of being an actual presentation of its environmental impact and achievements in this area? B. Mazur and K. Zimnoch indicate that the activities of housing cooperatives "fit perfectly into the concept of sustainable development, proving that the implementation of this concept does not always require revolutionary changes in the business world" [4]. Therefore, the authors ask why this type of entity, built on the values of sustainable development, has not been obligated yet to prepare CSR reports, as such reports cannot be found on websites or in non-financial reports prepared by the indicated entities (as it has been confirmed in this study). A discussion of this subject ought to be initiated and the idea should be put forward to incorporate in the common practice of housing cooperatives non-financial reports that should be prepared in accordance with the aforementioned Directive 2014/95/EU of the European Parliament and of the Council on disclosure of non-financial information and diversity policy of 22 October 2014 for such activities to become a new trend in the housing cooperative sector. The authors postulate the promotion of sustainable development, yet the future will show whether the principles of sustainable development will become an integral part of the activities of housing cooperatives, or whether the sustainable development "fad" will fade.

Author Contributions: Conceptualization, A.B. and S.J.; Data curation, A.B. and S.J.; Formal analysis, A.B. and S.J.; Funding acquisition, S.J.; Investigation, A.B. and S.J.; Methodology, A.B. and S.J.; Project administration, A.B.; Resources, A.B. and S.J.; Validation, A.B. and S.J.; Writing-original draft, A.B. and S.J.; Writing-review \& editing, A.B. and S.J. All authors have read and agreed to the published version of the manuscript.

Funding: This research received no external funding.

Institutional Review Board Statement: Not applicable.

Informed Consent Statement: Not applicable. 
Data Availability Statement: The data presented in this study are available on request from the corresponding author.

Acknowledgments: We wish to thank the Reviewers and the Academic Editor for valuable comments that have contributed to the further improvement of the article.

Conflicts of Interest: The authors declare no conflict of interest.

\section{Appendix A}

Table A1. Research questionnaire.

\begin{tabular}{|c|c|c|}
\hline Entity Studied & Items & $\begin{array}{c}\text { Subsequently Recorded } \\
100 \text { Housing } \\
\text { Cooperative Studied }\end{array}$ \\
\hline \multicolumn{3}{|c|}{ Website of the entity studied } \\
\hline \multicolumn{3}{|l|}{ Fiscal YEAR } \\
\hline \multicolumn{3}{|c|}{ I. GENERAL STANDARD DISCLOSURES } \\
\hline \multicolumn{3}{|c|}{ Strategy and Analysis: } \\
\hline \multicolumn{3}{|c|}{ G4-1 } \\
\hline \multicolumn{3}{|c|}{ Organisational Profile: } \\
\hline \multicolumn{3}{|c|}{ G4-3 } \\
\hline \multicolumn{3}{|c|}{ G4-4 } \\
\hline \multicolumn{3}{|c|}{ G4-5 } \\
\hline \multicolumn{3}{|c|}{ G4-6 } \\
\hline \multicolumn{3}{|c|}{ G4-7 } \\
\hline \multicolumn{3}{|c|}{ G4-8 } \\
\hline \multicolumn{3}{|c|}{ G4-9 } \\
\hline \multicolumn{3}{|c|}{ G4-10 } \\
\hline \multicolumn{3}{|c|}{ G4-11 } \\
\hline \multicolumn{3}{|c|}{ G4-12 } \\
\hline \multicolumn{3}{|c|}{ G4-13 } \\
\hline \multicolumn{3}{|c|}{ G4-14 } \\
\hline \multicolumn{3}{|c|}{ G4-15 } \\
\hline \multicolumn{3}{|c|}{ G4-16 } \\
\hline \multicolumn{3}{|c|}{$\begin{array}{l}\text { Identified Material Aspects and the } \\
\text { corresponding Boundaries: }\end{array}$} \\
\hline \multicolumn{3}{|c|}{ G4-17 } \\
\hline \multicolumn{3}{|c|}{ G4-18 } \\
\hline \multicolumn{3}{|c|}{ G4-19 } \\
\hline \multicolumn{3}{|c|}{ G4-20 } \\
\hline \multicolumn{3}{|c|}{ G4-21 } \\
\hline \multicolumn{3}{|c|}{ G4-22 } \\
\hline \multicolumn{3}{|c|}{ G4-23 } \\
\hline \multicolumn{3}{|c|}{ Stakeholder Engagement: } \\
\hline \multicolumn{3}{|c|}{ G4-24 } \\
\hline \multicolumn{3}{|c|}{ G4-25 } \\
\hline & G4-26 & \\
\hline & G4-27 & \\
\hline
\end{tabular}


Table A1. Cont.

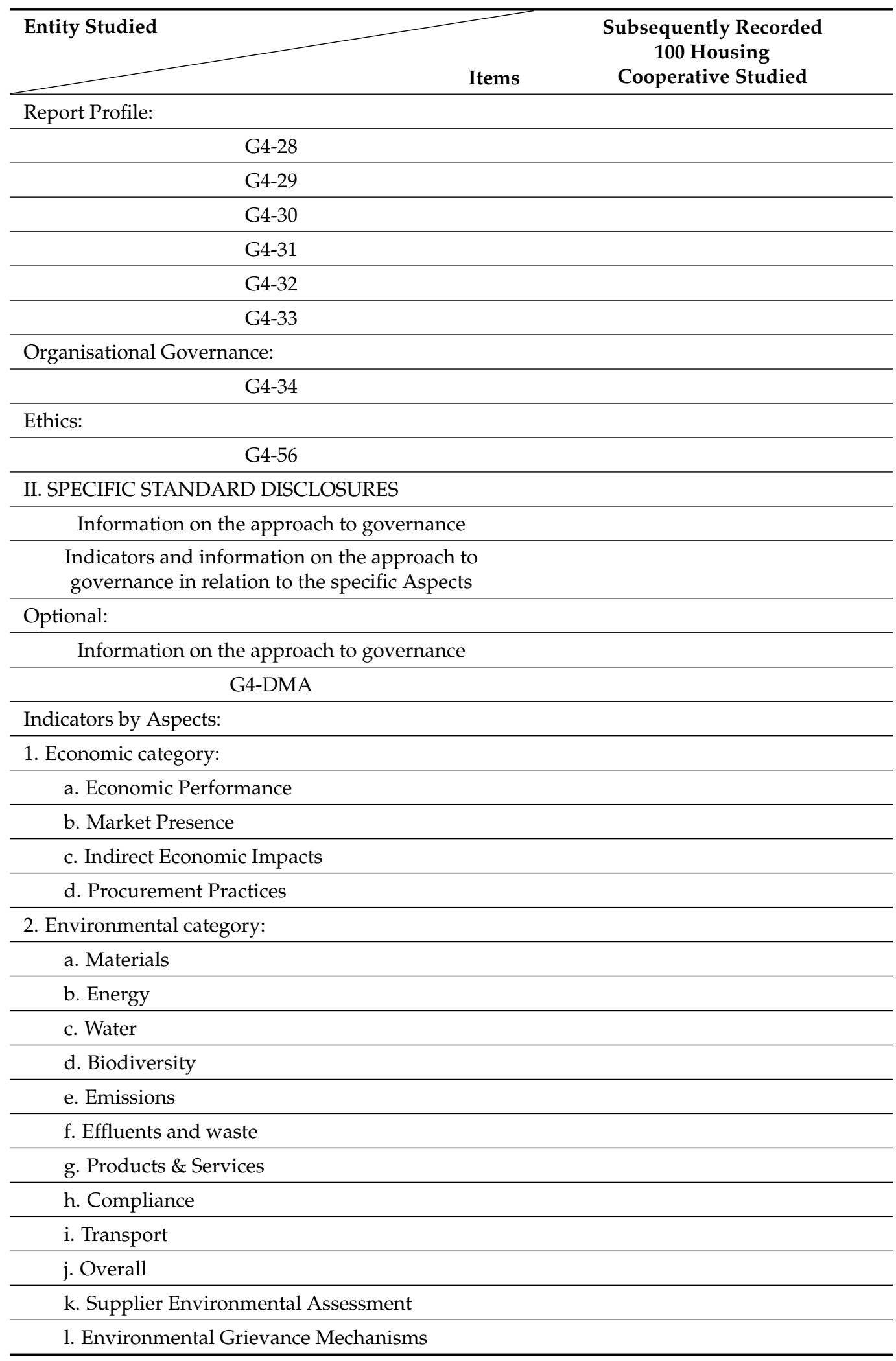


Table A1. Cont.

\begin{tabular}{|c|c|}
\hline Entity Studied & $\begin{array}{c}\text { Subsequently Recorded } \\
100 \text { Housing } \\
\text { Cooperative Studied }\end{array}$ \\
\hline \multicolumn{2}{|l|}{ 3. Social category: } \\
\hline \multicolumn{2}{|l|}{ 3.1. Labour Practices and Decent Work: } \\
\hline \multicolumn{2}{|l|}{ a. Employment } \\
\hline \multicolumn{2}{|l|}{ b. Employee/Management Relations } \\
\hline \multicolumn{2}{|l|}{ c. Occupational Health and Safety } \\
\hline \multicolumn{2}{|l|}{ d. Training and Education } \\
\hline \multicolumn{2}{|l|}{ e. Diversity and Equal Opportunity } \\
\hline \multicolumn{2}{|l|}{ f. Equal Remuneration for Women and Men } \\
\hline \multicolumn{2}{|l|}{ g. Supplier Assessment for Labour Practices } \\
\hline \multicolumn{2}{|l|}{ h. Labour Practices Grievance Mechanisms } \\
\hline \multicolumn{2}{|l|}{ 3.2. Human Rights } \\
\hline \multicolumn{2}{|l|}{ a. Investment } \\
\hline \multicolumn{2}{|l|}{ b. Non-discrimination } \\
\hline \multicolumn{2}{|l|}{$\begin{array}{l}\text { c. Freedom of Association and Collective } \\
\text { Bargaining }\end{array}$} \\
\hline \multicolumn{2}{|l|}{ d. Child Labour } \\
\hline \multicolumn{2}{|l|}{ e. Forced and Compulsory Labour } \\
\hline \multicolumn{2}{|l|}{ f. Security Practices } \\
\hline \multicolumn{2}{|l|}{ g. Indigenous Rights } \\
\hline \multicolumn{2}{|l|}{ h. Periodic Assessment System } \\
\hline \multicolumn{2}{|l|}{ i. Supplier Human Rights Assessment } \\
\hline \multicolumn{2}{|l|}{ j. Human Rights Grievance Mechanisms } \\
\hline \multicolumn{2}{|l|}{ 3.3. Society } \\
\hline \multicolumn{2}{|l|}{ a. Local Communities } \\
\hline \multicolumn{2}{|l|}{ b. Anti-corruption } \\
\hline \multicolumn{2}{|l|}{ c. Public Policy } \\
\hline \multicolumn{2}{|l|}{ d. Anti-competitive Behaviour } \\
\hline \multicolumn{2}{|l|}{ e. Compliance } \\
\hline \multicolumn{2}{|l|}{ f. Supplier Assessment for Impacts on Society } \\
\hline \multicolumn{2}{|l|}{ g. Grievance Mechanisms for Impacts on Society } \\
\hline \multicolumn{2}{|l|}{$\begin{array}{l}\text { 3.4. Product Responsibility Performance Indicators (e.g., } \\
\text { responsibility for buildings): }\end{array}$} \\
\hline $\begin{array}{l}\text { a. Customer Health and Safety (here: customers are } \\
\text { housing cooperative members) }\end{array}$ & \\
\hline b. Product and Service Labelling & \\
\hline c. Marketing Communications & \\
\hline $\begin{array}{l}\text { d. Customer Privacy (here: privacy of housing } \\
\text { cooperative members) }\end{array}$ & \\
\hline e. Compliance & \\
\hline COMMENTS & \\
\hline
\end{tabular}

Source: own elaboration based on Reference [27] (pp. 18-235). 


\section{References}

1. Fijałkowska, J.; Zyznarska-Dworczak, B.; Garsztka, P. Corporate Social-Environmental Performance versus Financial Performance of Banks in Central and Eastern European Countries. Sustainability 2018, 10, 772. [CrossRef]

2. Skoczylas, W. Społeczna odpowiedzialność biznesu w świetle analizy zawartości raportów niefinansowych spółek makrosektora produkcja przemysłowa i budowlano-montażowa. Zesz. Teor. Rachun. 2019, 103, 169-182. [CrossRef]

3. Lemańska-Majdzik, A. Flexible Activities of the Organization in Implementation of the Sustainable Development Principles in Selected Areas of the Organizations. Eur. J. Sustain. Dev. 2018, 7, 212-222. [CrossRef]

4. Mazur, B.; Zimnoch, K. Cooperatives' values in Poland and sustainable development. J. Bus. Manag. 2019, 5, 115-126.

5. Tcaciuc, C.; Hacina, L.; Alexandrin, G. Study on Corporate Social Responsibility of Cooperative Enterprises in the Republic of Moldova. Econ. Transdiscipl. Cogn. 2012, 15, 218-225.

6. Walczak, W. Funkcjonowanie rad nadzorczych w spółdzielniach mieszkaniowych. Przegląd Corp. Gov. 2011, 3, 45-54.

7. Konieczna, I. Model Biznesowy Spótdzielni a Model Biznesowy Przedsiębiorstw o Innej Formie Organizacyjno-Prawne; Wydawnictwo Dfifn S.A.: Warszawa, Poland, 2015.

8. Art. $1 \S 1$ of the Cooperative Law Act of 16 September, 1982 (Consolidated Text: Journal of Laws of 2003, No. 188, Item 1848, as Amended). Available online: http:/ /isap.sejm.gov.pl/isap.nsf/download.xsp/WDU20031881848/U/D20031848Lj.pdf (accessed on 23 February 2021).

9. Gospodarka Mieszkaniowa w 2018, r. Available online: https://stat.gov.pl/obszary-tematyczne/infrastruktura-komunalnanieruchomosci/nieruchomosci-budynki-infrastruktura-komunalna/gospodarka-mieszkaniowa-w-2018-roku, 14,2.html (accessed on 23 February 2021).

10. Spółdzielczość Mieszkaniowa. Available online: https://www.krs.org.pl/index.php/ruch-spodzielczy-sp-1235027511/branespodzielcze/spodzielczo-mieszkaniowa (accessed on 8 August 2017).

11. Blomé, G. Corporate social responsibility in housing management: Is it profitable? Prop. Manag. 2012, 30, 351-361. [CrossRef]

12. International Accounting Standards Committee. International Accounting Standards 1999; International Accounting Standards Committee: London, UK, 1999; pp. 46-48.

13. IFRS Foundation. Conceptual Framework for Financial Reporting; IFRS Foundation: London, UK, 2018; pp. 9-12.

14. Michalak, J. Podstawy teoretyczne sprawozdawczości zrównoważonego rozwoju a zakres jej zastosowania w Polsce i na świecie. In Teoria i Praktyka Wspótczesnej Rachunkowości. Zagadnienia Wybrane; Szychta, A., Ed.; Wydawnictwo Uniwersytetu łódzkiego: Łódź, Poland, 2011; p. 223.

15. Global Reporting Initiative G3 Sustainability Reporting Guidelines. Available online: https://download-pdfs.com/v6/preview/ ?pid=6\&offer_id=26\&ref_id=b977388345acffe72d87098d794j8D4n_d3178de1_c28f910b\&sub1=29298\&keyword=Global\%20 Reporting\%20Initiative\%20G3\%20Sustainability\%20Reporting\%20Guidelines (accessed on 12 May 2021).

16. Moir, L. What do We Mean by Corporate Social Responsibility Now? Theory Politics Organ. 2007, 7, 372-380.

17. Jensen, M.C.; Meckling, W.H. Theory of the firm: Managerial behavior, agency costs and ownership structure. J. Financ. Econ. 1976, 3, 305-360. [CrossRef]

18. Eisenhardt, K.M. Agency Theory: An Assessment and Review. Acad. Manag. Rev. 1989, 14, 57-74. [CrossRef]

19. Graves, S.B.; Waddock, S.A. Institutional Owners and Corporate Social Performance. Acad. Manag. J. 1994, 37, $1034-1046$.

20. Nita, B. Teoria uwarunkowań sytuacyjnych w rachunkowości zarządczej. Zesz. Teor. Rachun. 2013, 71, 193-209. [CrossRef]

21. Łada, M. Ugruntowane teorie o rachunkowości zarządczej. In Rachunkowość a Controlling; Nowak, E., Nieplowicz, M., Eds.; Wydawnictwo Uniwersytetu Ekonomicznego we Wrocławiu: Wrocław, Poland, 2014; p. 324.

22. Pham, H.T.T.; Jung, S.-C.; Lee, S.-Y. Governmental Ownership of Voluntary Sustainability Information Disclosure in an Emerging Economy: Evidence from Vietnam. Sustainability 2020, 12, 6686. [CrossRef]

23. Purtik, H.; Zimmerling, E.; Welpe, I.M. Cooperatives as catalysts for sustainable neighborhoods-A qualitative analysis of the participatory development process toward a 2000-Watt Society. J. Clean. Prod. 2016, 134, 112-123. [CrossRef]

24. Transforming Our World: The 2030 Agenda for Global Action. Available online: http:/ /www.un.org.pl/files/170/Agenda203 OPL_pl-5.pdf (accessed on 23 April 2021).

25. Konieczna, R. CSR i Jego Narzędzia Jako Element Strategii Firm-Praktyczny Przewodnik; Wydawnictwo IGSMiE PAN: Kraków, Poland, 2014.

26. Apanowicz, J. Metodologia Ogólna; Wydawnictwo Diecezji IVIplińskiej “BERNARDINUM”: Gdynia, Poland, $2002 ;$ pp. 62-63.

27. GRI G4 Podręcznik Stosowania Wytycznych Dot. Raportowania. Available online: https://www.gov.pl/attachment/8692a181-8 1ae-4788-bbaf-42e8fcea34e3 (accessed on 23 April 2021).

28. Niemiec, A. Kluczowe Mierniki Dokonań (KPI) w Zarządzaniu Organizacją na Gruncie Równowagi Funkcjonalnej; CeDeWu: Warszawa, Poland, 2019; pp. 39-40.

29. Szczepankiewicz, E.I.; Mućko, P. CSR Reporting Practices of Polish Energy and Mining Companies. Sustainability 2016, 8, 126. [CrossRef]

30. Aris, N.A.; Marzuki, M.M.; Othman, R.; Rahman, S.A.; Ismail, N.A.H. Designing indicators for cooperative sustainability: The Malaysian perspective. Soc. Responsib. J. 2018, 14, 226-248. [CrossRef] 